\title{
Hibernation of bats in post-Soviet military objects in Poland
}

\author{
Grzegorz WOJTASZYN ${ }^{1}$, Wojciech STEPHAN ${ }^{1}$, Tomasz RUTKOWSKI ${ }^{2}$, Radosław JAROS ${ }^{1}$, \\ Maurycy IGNACZAK ${ }^{3}$, Grzegorz LESIŃSKI ${ }^{4}$ \\ ${ }^{1}$ Polish Society for Nature Protection "Salamandra", Stolarska 7/3, 60-788 Poznań, Poland; \\ e-mail:grzegwojt2@wp.pl,wssteven@wp.pl,radek@salamandra.org.pl \\ ${ }^{2}$ Natural History Collections, Faculty of Biology, Adam Mickiewicz University in Poznań, \\ Uniwersytetu Poznańskiego 6, 61-614 Poznań, Poland; e-mail: pardosa@gazeta.pl \\ ${ }^{3}$ Polish Society for Bat Protection, Wojska Polskiego 28,60-637 Poznań, Poland; e-mail: imoris@ksiezyc.pl \\ ${ }^{4}$ Institute of Animal Sciences, Warsaw University of Life Sciences (SGGW), Ciszewskiego 8, 02-787 Warsaw, Poland; \\ e-mail: glesinski@wp.pl
}

\begin{abstract}
In the years 2004-2018, data on bats wintering in 9 sites of the Northern Group of the Soviet Army (PGWAR) stationed in the years 1945-1993 in Poland were obtained. A total of at least 11 bat species were found: greater mouseeared bat Myotis myotis, Natterer's bat M. nattereri, Daubenton's bat M. daubentonii, Bechstein's bat M. bechsteinii, whiskered/Brandt's/Alcathoe bats M. mystacinus/brandtii/alcathoe, brown long-eared bat Plecotus auritus, grey longeared bat $P$. austriacus, western barbastelle Barbastella barbastellus, serotine bat Eptesicus serotinus, common noctule Nyctalus noctula, common pipistrelle Pipistrellus pipistrellus and bats determined to the genus Pipistrellus. From 6 to 449 individuals hibernated in the facilities. Noteworthy is the presence of three species from Annex II of the Habitats Directive of EU. In most of the facilities, M. myotis and B. barbastellus were found, and M. bechsteinii in Wilkocin only. Wintering sites were used by numerous bats and also by endangered species therefore those buildings should be advisable to be covered with forms of nature protection.
\end{abstract}

Key words: Chiroptera, wintering sites, fortifications, species composition, colonization of roosts, central Europe

\section{INTRODUCTION}

Most bat species hibernate in underground structures in climate of central Europe. Abandoned military facilities with their extensive underground corridors are suitable roosts for wintering of these mammals (Voigt et al. 2014). In west and central Poland the bats from the genus Myotis (excluding a group of species - Myotis mystacinus complex) hibernate in warmer and more humid places, while the species from the genera: Eptesicus, Plecotus and Barbastella in colder and less humid places (Bogdanowicz \& Urbańczyk 1983, Lesiński 1986).

In Poland, there are many bat wintering sites in former military facilities (Lesiński 2006). Bat hibernation was recorded in medieval castles (Stec \& Kasprzyk 2004, Stec et al. 2008), fortresses built in 19th century (Lesiński 1988, Jurczyszyn et al. 2002, Kasprzyk et al. 2002, Lesiński \& Kowalski 2002, Fuszara et al. 2010) or bunkers from the World War II (Urbańczyk 1989, 1991, Sachanowicz \& Zub 2002, Wojtaszyn et al. 2003, Bernard et al. 2019), but not much data comes from bunkers created after the World War II, used by the Soviet Army until the nineties of the 20th century. These sites are characterized by the presence of underground spaces and good thermic isolation from external conditions (Szulc \& Nicpoń 2007, Szulc 2010, Piotrowski 2017), which creates a suitable habitat for wintering of bats. They also can be regularly used by species mentioned in Annex II of the Habitats Directive of EU (Directive 1992). Relatively late time when they were abandoned gives us the opportunity to study processes of colonization of new hibernacula by bats. 
The aim of the work is to determine the species composition and changes in the number of wintering bats in selected post-Soviet military facilities located in the western part of Poland. Observations were made regarding the settlement of bats in these objects after cessation of their use, as well as the importance of this type of shelters for bats. Military facilities can be potentially devastated and lost, so monitoring of bats should allow to make decisions concerning the protection of these sites.

\section{STUDY AREA AND METHODS}

In the years 2004-2018 inspections of selected military buildings of the Northern Group of the Soviet Army (PGWAR) stationed in the years 1945-1993 (Krogulski 2002) in Poland were carried out. The garrisons were located mainly in western Poland. The objects were built after 1945. Most of the sites described were abandoned along with the withdrawal of Soviet troops stationed in Poland - in 1992 or in 1993. Later some of them have been used by the Polish Army for some time. Most roosts described are two-level facilities. The publication presents data from nine sites: five command posts, two that served as nuclear weapons storage (Piotrowski 2017), communication system facilities of Warsaw Pact countries and infrastructure of the missile brigade. Some of them are single objects, and some are complexes of objects located close to each other.

Description of the inventoried objects based mainly on data presented by Szulc \& Nicpoń (2007) and Szulc (2010). Numbers of UTM squares and numbers of squares according to Atlas of Polish Mammals (Atlas 2020) were given for all examined positions (Fig. 1).

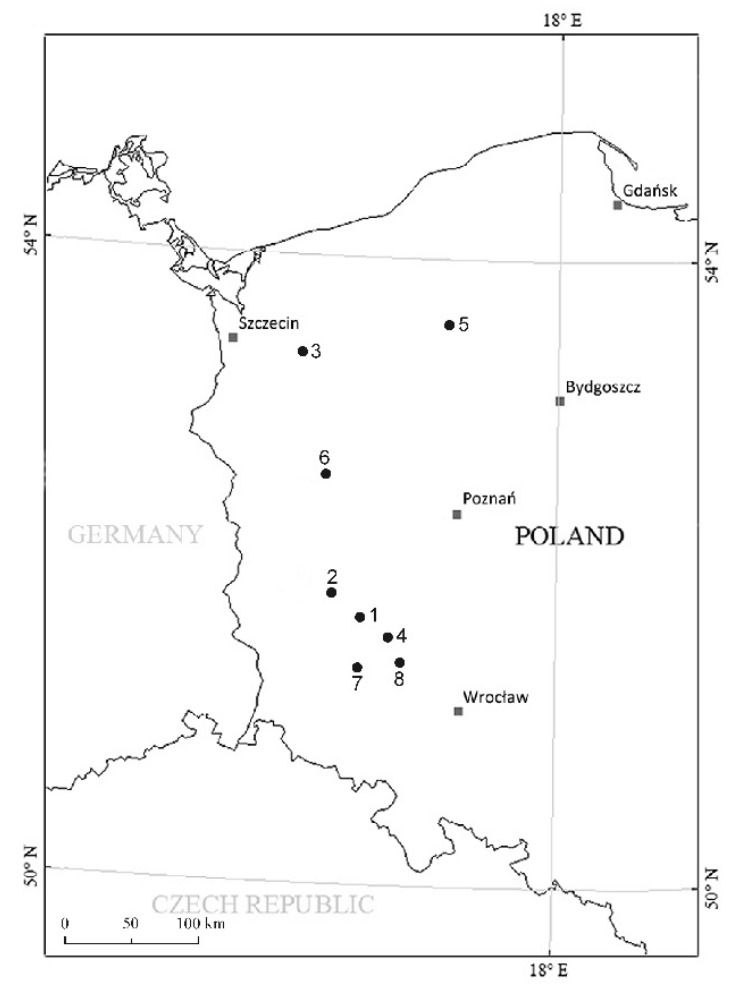

Fig. 1. Localization of study sites. Position numbers as in the text. 
1. Szprotawa-Wiechlice - a shelter surveyed in 2004-2018 at the former Soviet military airport (UTM WT31, Atlas of Polish Mammals 04Kd, Lubuskie Voivodeship, Szprotawa commune) - command post of the bomber division stationed until 1993 in Szprotawa. The object is a two-level bunker, built of prefabricated concrete elements covered with soil (Szulc 2010). Abandoned by the military in 1992 (Boryna 2006).

2. Żagań-Tomaszowo - a shelter surveyed in 2006-2009 at the former post-Soviet military airport (UTM WT21, Atlas of Polish Mammals 03Kc, Lubuskie Voivodeship, Żagań commune) - twin with a facility in Szprotawa, a two-level bunker being the command post of the aviation division. Object abandoned by the military in 1992 (Boryna 2006). In 2009, it was managed in a way that makes hibernation of bats impossible.

3. Stargard-Kluczewo - a shelter surveyed in 2012-2018 at the former post-Soviet military airport (UTM WT 90, Atlas of Polish Mammals 02Fc, West Pomerania Voivodeship, Stargard Municipality) - a two-level structure similar to those described above - command post of the fighter aviation division (Szulc 2010). An underground facility, buried in a slope. The use of the airport with the building was discontinued in 1992. Data from 2012 were previously published (Wojtaszyn et al. 2014).

4. Wilkocin I and Wilkocin II - bunkers surveyed in: 2006, 2012-2016 and 2018 (UTM WT50, Atlas of Polish Mammals 04Kh, Lower Silesia Voivodeship, Przemków commune) extensive underground structures that were the Spare Command Post of the Western Theatre of the War Activities (Wilkocin I) and the Command Post of the Northern Group of the Soviet Army (Wilkocin II) (Szulc 2010). Abandoned by the Soviet Army in 1992, but one of the buildings located more to the south-east (Wilkocin II) for some time was used by the Polish Army. Data on wintering bats in these facilities from 1997-1999 were presented in the atlas of bat distribution in south-western Poland (Szkudlarek et al. 2002). This work presents data from the Wilkocin I and Wilkocin II shelters separately. In the case of Wilkocin I taken into account are the data from the main shelter and two small objects located in its immediate vicinity: the socalled Stróżówka (Guard-house) and Hangar.

5. Brzeźnica Kolonia near Jastrowie - nuclear weapons storage facility surveyed in 2008 and 2011-2018 (UTM XV 02, Atlas of Polish Mammals 06Eg, Wielkopolskie Voivodeship, Jastrowie commune) - two underground two-storey warehouses located in the former Soviet military base, in which heads for missiles and nuclear air bombs were stored. The object was abandoned by the Russians in 1992, until 1995 it was supervised by the Polish Army (Szulc \& Nicpoń 2007). In table 1 data from both objects are presented together.

6. Templewo near Trzemeszno Lubuskie - nuclear weapons storage facility surveyed in 2013-2018 (UTM WU 20, Atlas of Polish Mammals 03Hi, Lubuskie Voivodeship, municipality of Sulęcin) - two twin objects to the warehouse in Brzeźnica Kolonia, also two-level and used for nuclear weapons storage (Piotrowski 2017). The military base was abandoned by the Russians in 1992, for several subsequent years it was in the military training ground (Szulc \& Nicpoń 2007). In table 1 data from both objects are presented together.

7. Trzebień - bunker surveyed in 2006, 2012 and 2014 (UTM WS 49, Atlas of Polish Mammals $04 \mathrm{Kj}$, Lower Silesia Voivodeship, Bolesławiec commune) - the facility constituting the infrastructure of the PGWAR missile brigade with auxiliary units that was stationed there from 1970s to 1992. Abandoned by the Soviet Army in 1993.

8. Chocianów - bunker surveyed in 2016 (BARS) (UTM WS 69, Atlas of Polish Mammals 04Ki, Lower Silesia Voivodeship, Chocianów commune) - a two-level facility for servicing the military system of tropospheric communication of the Warsaw Pact countries. Abandoned by the Russians in 1992 or in 1993.

Information on the occurrence of bats in two of these wintering grounds has already been mentioned in other papers (Paszkiewicz 2000, Szkudlarek et al. 2002, Wojtaszyn et al. 2014). 
Some facilities were regularly inspected, others only in selected years (Table 1). In most cases species of hibernating bats were determined on the basis of external features without awakening them. When there was no possibility of certain determination to the species level, the animals hidden deep in the crevices were referred to as Chiroptera indeterminata (indet). Bats from the group M. mystacinus/brandtii/alcathoe, were treated together as M. mystacinus complex. In addition, some individuals were only classified to the genus Pipistrellus.

Species diversity was estimated by using $S$ index calculated as $1 / \sum \mathrm{p}_{\mathrm{i}}{ }^{2}$, where $\mathrm{p}_{\mathrm{i}}$ is contribution of $i$ species among all bat species. To test statistically significant trends in bat abundance in each roosts within the study period, coefficients of Spearman rank correlation $\left(\mathrm{r}_{\mathrm{s}}\right)$ were calcutated with adopted significance level $\mathrm{p}=0.05$.

\section{RESULTS}

A total of at least 11 species of bats hibernating in the study area were found: greater mouseeared bat Myotis myotis (Borkhausen, 1797), Natterer's bat M. nattereri (Kuhl, 1817), Daubenton's bat M. daubentonii (Kuhl, 1817), Bechstein's bat M. bechsteinii (Kuhl, 1817), whiskered/Brandt's/Alcathoe bats M. mystacinus/brandtii/alcathoe, brown long-eared bat Plecotus auritus (Linnaeus, 1758), grey long-eared bat P. austriacus (Fischer, 1829), western barbastelle Barbastella barbastellus (Schreber, 1774), serotine bat Eptesicus serotinus (Keyserling et Blasius, 1839), common noctule Nyctalus noctula (Schreber, 1774), common pipistrelle Pipistrellus pipistrellus (Schreber, 1774) and bats determined to the genus Pipistrellus.

The highest number of individuals was found in Stargard-Kluczewo - 496, in Brzeźnica Kolonia 105, in Szprotawa-Wiechlice 96, in Templewo 76, and in Wilkocin I - 62. In the remaining facilities, a maximum of 6 to 38 individuals were recorded (Appendix).

Species richness was high in both bunkers in Wilkocin and in Stargard-Kluczewo - at least eight species. In Brzeźnica Kolonia and Szprotawa-Wiechlice, seven species were found. In the remaining surveyed stands from 2 to 5 bat species hibernated (Table 1).

Table 1. Species composition of hibernating bats, proportion of individuals belonging to the genus Myotis (more thermophilous species) vs. Plecotus, Barbastella and Eptesicus (M/PBE), and species diversity (S) in winter sites under study (index $\mathrm{S}$ was calculated taking into account only bats determined to the species level; bats from the genus Pipistrellus were classified to one species).

\begin{tabular}{|c|c|c|c|c|c|c|c|c|c|c|c|c|c|c|c|c|c|}
\hline Site & Years & $\begin{array}{l}\vdots \\
\vdots \\
\vdots \\
\vdots \\
\vdots \\
0 \\
\vdots \\
\Sigma\end{array}$ & 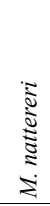 & 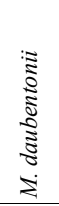 & 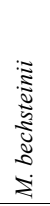 & 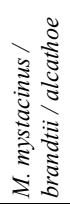 & 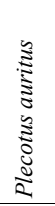 & 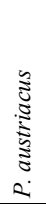 & 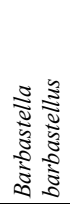 & 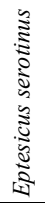 & 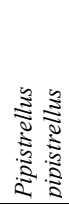 & 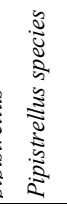 & 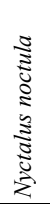 & 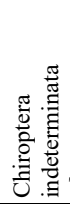 & Total & $\begin{array}{l}\mathrm{M} / \\
\mathrm{PBE}\end{array}$ & $\mathrm{S}$ \\
\hline Brzeźnica & & & & & & & & & & & & & & & & & \\
\hline $\begin{array}{l}\text { Kolonia } \\
\text { Żagań- }\end{array}$ & 2008-2018 & 81 & 43 & 86 & 0 & 1 & 154 & 0 & 6 & 27 & 3 & 11 & 0 & 31 & 443 & 1.13 & 0.81 \\
\hline Tomaszowo & 2006-2009 & 1 & 0 & 0 & 0 & 0 & 15 & 17 & 74 & 19 & 0 & 1 & 0 & 0 & 127 & 0.01 & 0.61 \\
\hline $\begin{array}{l}\text { Szprotawa- } \\
\text { Wiechlice }\end{array}$ & 2004-2018 & 1 & 0 & 1 & 0 & 0 & 85 & 17 & 507 & 0 & 0 & 1 & 0 & 6 & 618 & 0.00 & 0.29 \\
\hline $\begin{array}{l}\text { Templewo } \\
\text { Stargard- }\end{array}$ & 2012-2018 & 0 & 2 & 6 & 0 & 0 & 82 & 0 & 223 & 9 & 0 & 4 & 0 & 5 & 331 & 0.03 & 0.47 \\
\hline Kluczewo & 2012-2018 & 39 & 326 & 124 & 0 & 2 & 96 & 0 & 72 & 55 & 0 & 1803 & 0 & 66 & 2583 & 2.20 & 0.46 \\
\hline Wilkocin I & 2006-2018 & 21 & 0 & 1 & 3 & 0 & 104 & 76 & 90 & 27 & 0 & 0 & 2 & 2 & 326 & 0.08 & 0.76 \\
\hline Wilkocin II & $2012-2018$ & 6 & 0 & 15 & 1 & 0 & 40 & 33 & 24 & 15 & 0 & 0 & 0 & 3 & 137 & 0.20 & 0.79 \\
\hline Trzebień & 2006-2014 & 0 & 0 & 0 & 0 & 0 & 4 & 6 & 0 & 0 & 0 & 0 & 0 & 0 & 10 & 0 & 0.48 \\
\hline Chocianów & 2016 & 0 & 0 & 0 & 0 & 0 & 19 & 0 & 2 & 0 & 0 & 0 & 0 & 0 & 22 & 0 & 0.18 \\
\hline
\end{tabular}


The highest species diversity was observed in Brzeźnica Kolonia and Wilkocin while the lowest values were obtained for Chocianów and Szprotawa-Wiechlice. Two sites were characterized by a relatively high proportion of bats belonging to the genus Myotis, which prefer warmer places than bats from the genus Plecotus, Barbastella and Eptesicus) (over 1.0). In the remaining sites this proportion varied from 0 to 0.2 (Table 1 ).

Statistically important trends in changes in numbers were shown for some species: M. myotis in Brzeźnica Kolonia and Stargard-Kluczewo, M. nattereri in Brzeźnica Kolonia, B. barbastellus in Szprotawa-Wiechlice, E. serotinus in Szprotawa-Wiechlice. No trends were recorded in $M$. daubentonii and species from the genus Plecotus. Declining tendency (not confirmed statistically) was marked in Pipistrellus spp. Total number of hibernating bats showed upward trends in Brzeźnica Kolonia, Szprotawa-Wiechlice and Templewo (Table 2).

Table 2. Trends in long-term changes in numbers of selected species in the hibernacula under study; in the upper row the Spearman correlation coefficient $r_{s}$ is given, in the lower row - the probability level $p$; statistically important relationships are in bold.

\begin{tabular}{|c|c|c|c|c|c|c|c|c|c|c|}
\hline Site & $\begin{array}{c}\mathrm{N} \\
\text { (years) }\end{array}$ & 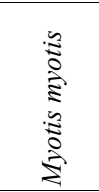 & 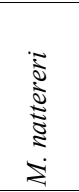 & 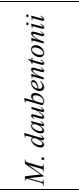 & 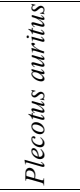 & 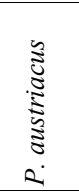 & 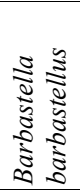 & 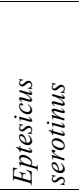 & 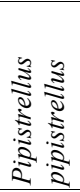 & Total \\
\hline \multirow{2}{*}{$\begin{array}{l}\text { Brzeźnica } \\
\text { Kolonia }\end{array}$} & 9 & 0.95 & 0.80 & 0.58 & 0.57 & - & - & -0.02 & - & 0.88 \\
\hline & & $<0.001$ & 0.016 & 0.099 & 0.112 & & & 0.955 & & 0.002 \\
\hline \multirow{2}{*}{$\begin{array}{l}\text { Szprotawa- } \\
\text { Wiechlice }\end{array}$} & 13 & - & - & - & -0.09 & - & 0.76 & 0.75 & - & 0.75 \\
\hline & & & & & 0.760 & & 0.003 & 0.003 & & 0.003 \\
\hline \multirow[t]{2}{*}{ Templewo } & 7 & - & - & - & 0.36 & - & 0.71 & - & - & 0.86 \\
\hline & & & & & 0.432 & & 0.071 & & & 0.014 \\
\hline \multirow{2}{*}{$\begin{array}{l}\text { Stargard- } \\
\text { Kluczewo }\end{array}$} & 7 & 0.83 & 0.71 & 0.67 & - & - & - & - & -0.68 & -0.32 \\
\hline & & 0.042 & 0.071 & 0.102 & & & & & 0.094 & 0.482 \\
\hline \multirow[t]{2}{*}{ Wilkocin I } & 7 & 0.03 & - & - & -0.25 & 0.71 & 0.41 & - & - & 0.50 \\
\hline & & 0.956 & & & 0.589 & 0.074 & 0.355 & & & 0.253 \\
\hline
\end{tabular}

\section{DISCUSSION}

Little is known on the subject of bats in post-Soviet facilities in Poland. The only information concerns the bunkers in Wilkocin (Paszkiewicz 2000, Szkudlarek et al. 2002) and the shelter in Stargard-Kluczewo (Wojtaszyn et al. 2014). Our study shows that the inspected sites were intensively used by bats and also by endangered species during the hibernation period.

Bat colonization of anthropogenic sites after discontinuation of use is usually long-term (̌̌ehák \& Gaisler 1999, Mitchell-Jones et al. 2007). It is probably related to the necessity of creating the proper microclimate inside the underground (gradual increase of humidity) and "getting to know" a given position (Parsons \& Jones 2003, Lesiński 2006). Processes responsible for finding the object by bats are probably associated with their non-hibernation activity at the undergrounds, so-called swarming (Parsons et al. 2003, Ciechanowski et al. 2004).

In some objects a distinct increase in the number of bats was observed e.g. in SzprotawaWiechlice during the first inspection in 2004, seven individuals were wintering, and since 2010 the number of hibernating individuals has not usually dropped below 60 (maximum of 96 individuals in 2017). In this shelter, attention is paid to a significant increase in the number of wintering barbastelle bats from three individuals in 2004 to 74 in 2017. A visible increase in the number of hibernating bats was also observed in Kolonia Brzeźnica near Jastrowie (from 21 individuals in 2008 to 105 individuals in 2014). Within this position, especially the number of brown long-eared bats (from 11 to 42 in 2018) and greater mouse-eared bats (from 2 to 21 individuals in 2018) rose significantly. 
It should be added that in the majority of studied wintering grounds, treatments were not performed in order to adapt them to the needs of bats. The only objects in which the activities involving the increase of humidity and the installation of additional artificial shelters for wintering bats inside the underground were bunkers in Wilkocin I and II (Paszkiewicz 2000). Issues related to the rate of settlement of objects after cessation of their use by humans are poorly researched (Daan 1980, Lesiński et al. 2011). The data presented in this work show that for some of them, after about 20 years of leaving them, they become important wintering grounds on a regional scale, e.g. shelters in Stargard-Kluczewo, Wilkocin, Szprotawa-Wiechlice or Kolonia Brzeźnica. Noteworthy is the presence of species from Annex II of the Habitats Directive of European Union (Directive 1992). In most of the facilities, M. myotis and B. barbastellus were found, and $M$. bechsteinii in Wilkocin only. There are strong fluctuations in numbers in some roosts. In Templewo the number dropped from 42 in 2013 to 11 in 2014. In Stargard-Kluczewo there was a decrease in the number of bats from 496 in 2012 to 259 a year later, and in 2014 the number of individuals increased to 449, while in 2018, there were 284 specimens. In SzprotawaWiechlice there was a decrease to 38 individuals in 2016, from 66 observed a year earlier, in subsequent years there was an increase again. It is difficult to characterize the reasons for such fluctuations, they may result from weather conditions in individual years of research. Some of the cold-loving species during mild winters can periodically stay in other types of shelters and settle well-isolated objects (such as the bunkers in discuss) only in periods of severe frost (Rebelo et al. 2010). The anthropogenic impact is also not excluded, as in some objects the effects of acts of vandalism were observed, consisting mainly of burning fire inside the underground.

We conclude that all sites under study have a local significance for bats now. In the case of most roosts it would be advisable to cover them with some forms of nature protection, for example „użytek ekologiczny”, to protect against possible changes in the development of the buildings themselves or in their immediate surroundings.

\section{ACKNOWLEDGEMENTS}

We would like to thank all those involved in the inventories, in particular: Adam Chlebowski, Andrzej Gawlak, Simon Ghanem, Janusz Jabłoński, Karolina Jamska, Volker Kelm, Kamil Kryza, Michał Skierawski, Artur Stanilewicz and Dorota Wiewióra. We would like to thank Krzysztof Michalak for providing the literature on the objects studied. We would like to thank the Jastrowie Forest District, the Chocianów Forest District and Maciej Boryna for enabling the research. We also send thanks to the administration of Przemkowski Landscape Park, in particular to Marek Cieślak and Anna Walner.

\section{REFERENCES}

ATLAS 2020. Atlas of Polish Mammals. Institute of Nature Conservation PAS. Available from: http://www.iop.krakow.pl/atlas_of_mammals_polish_2_157.htmlhttp (January 2020).

BERNARD R., JAROS R., SAMOLĄG J \& KOSICKI J. Z. 2019. Long-term monitoring of a winter bat assemblage revealed large fluctuations and trends in species abundance. European Journal of Ecology5 (2): 72-78.

BogdANOWICZ W. \& URBAŃCZYK Z. 1983. Some ecological aspects of bats hibernating in city of Poznań. Acta Theriologica 28: 371-385. BoRYNA M. 2010. Encyklopedia Ziemi Szprotawskiej i Żagańskiej. Towarzystwo Bory Dolnośląskie, Szprotawa, 99 pp.

BORYNA M. 2006. Tajemnice militarne Szprotawy na Dolnym Śląsku. Szprotawa, 45 pp.

CiechanowsKi M., SZKUDLAREK R., DUDEK I. \& PIKSA K. 2004. Aktywność nietoperzy w otworach kryjówek podziemnych poza okresem hibernacji w Polsce - przegląd dotychczasowych danych. Nietoperze 4: 85-94.

DAAN S. 1980. Long term changes in bat populations in the Netherlands: a summary. Lutra 22: 95-105.

DIRECTIVE 1992. Council Directive 92/43/EEC of 21 May 1992 on the conservation of natural habitats and of wild fauna and flora. Available from: https://eur-lex.europa.eu/legal-content/EN/TXT/?uri=CELEX:31992L0043 (January 2020). 
Fuszara E., Fuszara M., Kowalski M., Lesiński G., Cygan J.P., NitKieWicZ T., Szarlik A. \& WojtowiCZ B. 2010. Population changes in Natterer's bat Myotis nattereri and Daubenton's bat M. daubentonii in winter roosts of central Poland. Polish Journal of Ecology 58: 769-781.

JuRCZYSZYN M., GAWLAK A., DZIĘCIOŁOWSKi R. \& KePEl A. 2002. Zimowe spisy nietoperzy w Poznaniu w latach 1979-1999. Nietoperze 3: 77-87.

KASPRZYK K., RUCZYŃSKA I. \& WOJCIECHOWSKI M. 2002. Zimowy spis nietoperzy na Pomorzu Nadwiślańskim w latach 1996-1999. Nietoperze 3: 39-52.

KrogulsKi M. L. 2002. Okupacja w imię sojuszu. Armia Radziecka w Polsce 1956-1993. Wydawnictwo von Borowiecky, Warszawa, 263 pp.

LESIŃSKI G. 1986. Ecology of bats hibernating underground in Central Poland. Acta Theriologica 31: 507-521.

LESIŃSKI G. 1988. Skład gatunkowy i liczebność nietoperzy w fortach modlińskich w ciągu roku. Przegląd Zoologiczny 32: $576-587$.

LESIŃSKI G. 2006. Wpływ antropogenicznych przekształceń krajobrazu na strukturę i funkcjonowanie zespołów nietoperzy w Polsce. Wydawnictwo SGGW, Warszawa, 212 pp.

LESIŃSKI G., IGNACZAK M. \& KOWALSKI M. 2011. Increasing bat abundance in a major winter roost in central Poland over 30 years. Mammalia 75: 163-167.

LESIŃSKI G. \& KOWALSKI M. 2002. Zimowy monitoring nietoperzy w Dolinie Narwi i Biebrzy w latach 1992-1999. Nietoperze 3: 53-60.

Mitchell-Jones A. J., Bihari Z., Masing M. \& Rodrigues L. 2007. Protecting and managing underground sites for bats. Eurobats Publication 2: 1-38.

PARSONS K. N. \& JONES G. 2003. Dispersion and habitat use by Myotis daubentonii and Myotis nattereri during the swarming season: implications for conservation. Animal Conservation 6: 283-290.

Parsons K. N., Jones G., Davidson-Watts I. \& Greenaway F. 2003. Swarming of bats at underground sites in Britain - implications for conservation. Biological Conservation 111: 63-70.

PASZKIEWICZ R. 2000. Adaptacja poradzieckiego bunkra w Przemkowskim Parku Krajobrazowym. Biuletyn ,pro Natura" 1: 28.

PIOTROWSKi P. 2017. Operacja „Wisła”. Broń jądrowa na terytorium Polski. Przegląd Historyczno-Wojskowy 1/259: 67-87.

ReBelo H., TARRoso P. \& JONES G. 2010. Predicted impact of climate change on European bats in relation to their biogeographic patterns. Global Change Biology 16: 561-576.

ŘEHÁK Z. \& GAISLER J. 1999. Long-term changes in the number of bats in the largest man-made hibernaculum of the Czech Republic. Acta Chiropterologica 1: 113-123.

SACHANOWICZ K. \& ZUB K. 2002. Numbers of hibernating Barbastella barbastellus (Schreber, 1774) (Chiroptera, Vespertilionidae) and thermal conditions in military bunkers. Mammalian Biology 67: 179-184.

STEC I., GOMUŁKA M., LESZCZYŃSKI M. \& KASPRZYK K. 2008. Nietoperze zimujące na zamku w Kwidzynie. Nietoperze 9: 90-92.

STEC I. \& KASPRZYK K. 2004. Nietoperze zimujące na terenie Zamku Krzyżackiego w Malborku w sezonach 2001/2002 - 2003/2004. In: Kasprzyk K. (ed), Materiały XVIII Ogólnopolskiej Konferencji Chiropterologicznej, Toruń 57.11.2004: 23-24.

Szkudlarek R., Paszkiewicz R., Hebda G., Gottfried T., Cieślak M., Mika A. \& Ruszlewicz A. 2002. Atlas rozmieszczenia nietoperzy w południowo-zachodniej Polsce - stanowiska zimowe z lat 1982-2002. Nietoperze 3: 197-235.

SZULC T. 2010. Radzieckie umocnione stanowiska dowodzenia w Polsce. Poligon 2: 62-72.

SZULC T. \& NiCPOŃ K. 2007. Magazyny broni jądrowej na terytorium Polski. Poligon 3: 62-77.

URBAŃCZYK Z. 1989. Results of the winter census of bats in Nietoperek 1985-1989. Myotis 27: 139-145.

URBAŃCZYK Z. 1991: Hibernation of Myotis daubentoni and Barbastella barbastellus in Nietoperek bat reserve. Myotis 29: 115-120.

Voigt C.C., Lehnert L.S., Popa-Lisseanu A.G,. Ciechanowski M., EstóK P., Gloza-Rausch F., GÖRFÖL T., Göttsche M., Harrje C., Hötzel M., Hötzel M., Teige T., Wohlgemuth R. \& Kramer-Schadt S. 2014. The trans-boundary importance of artificial bat hibernacula in managed European forests. Biodiversity and Conservation 23: 617-631.

WoJTASZYN G., GAWLAK A., GAWLAK M., RUTKOWSKi T. \& WiEWIÓRA D. 2003. Nietoperze zimujące w umocnieniach Wału Pomorskiego (1999-2003). Studia Chiropterologica 3-4: 49-58.

WoJTASZYN G., StePHAN W., JAROS R. 2014. Cenne zimowisko nietoperzy na Pomorzu Zachodnim. Nietoperze 13: 51-53.

\section{STRESZCZENIE}

\section{[Zimowanie nietoperzy w poradzieckich obiektach militarnych w Polsce]}

Przedstawiono dane o zimowaniu nietoperzy z lat 2004-2018 w 9 opuszczonych obiektach militarnych Północnej Grupy Wojsk Armii Radzieckiej (PGWAR) stacjonujących w Polsce w latach 1945-1993. Ogółem stwierdzono co najmniej 11 gatunków nietoperzy: nocka dużego 
Myotis myotis, nocka Natterera $M$. nattereri, nocka rudego $M$. daubentonii, nocka Bechsteina $M$. bechsteinii, nocka wąsatka/Brandta/alkatoe M. mystacinus/brandtii/alcathoe, gacka brunatnego Plecotus auritus, gacka szarego P. austriacus, mopka zachodniego Barbastella barbastellus, mroczka późnego Eptesicus serotinus, borowca wielkiego Nyctalus noctula, karlika malutkiego Pipistrellus pipistrellus oraz nietoperze zaliczone do rodzaju Pipistrellus. Od 6 do 449 osobników zimowało w badanych obiektach. Godna uwagi jest obecność gatunków z załącznika II Dyrektywy Siedliskowej Unii Europejskiej. W większości obiektów występowały nocki duże i mopki zachodnie, a nocek Bechsteina tylko w Wilkocinie. Wszystkie zimowiska mają obecnie lokalne znaczenie dla nietoperzy. W przypadku większości badanych budowli wskazane byłoby objęcie ich odpowiednimi formami ochrony przyrody, na przykład jako użytki ekologiczne, w celu ochrony przed możliwymi niekorzystnymi zmianami w ich wnętrzach i najbliższym otoczeniu. 
Appendix. Species composition and abundance of bats during each inspection of wintering sites in 2004-2018; * - bats were surveyed only in one object - the other was not available, ** - data from 2012 has already been published (Wojtaszyn et al. 2014).

\begin{tabular}{|c|c|c|c|c|c|c|c|c|c|c|c|c|c|c|c|}
\hline Site & Date & 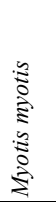 & 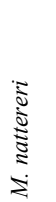 & 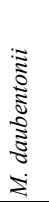 & 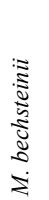 & 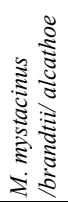 & 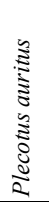 & 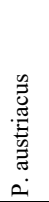 & 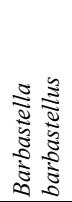 & 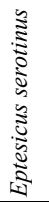 & 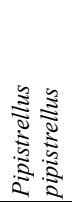 & 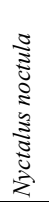 & 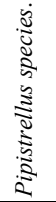 & 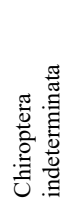 & Total \\
\hline \multirow{9}{*}{$\begin{array}{l}\text { Brzeźnica } \\
\text { Kolonia }\end{array}$} & 15.01 .2008 & 2 & 3 & 1 & & & 11 & & & & & & 4 & & 21 \\
\hline & 15.02 .2011 & 3 & & 3 & & 1 & 6 & & & 2 & & & 3 & & 18 \\
\hline & 04.02 .2012 & 4 & 3 & 15 & & & 10 & & 1 & 3 & 1 & & & 1 & 38 \\
\hline & 18.01 .2013 & 3 & 6 & 2 & & & 23 & & & 4 & & & & 2 & 40 \\
\hline & 04.02 .2014 & 12 & 3 & 18 & & & 18 & & & 6 & 2 & & & 2 & 61 \\
\hline & 21.02 .2015 & 6 & 3 & 6 & & & 9 & & 1 & 1 & & & 1 & & 27 \\
\hline & 04.02 .2016 & 15 & 7 & 12 & & & 20 & & 1 & 6 & & & 1 & 1 & 63 \\
\hline & 28.02 .2017 & 15 & 7 & 13 & & & 15 & & 1 & 3 & & & 1 & 15 & 70 \\
\hline & 02.02 .2018 & 21 & 11 & 16 & & & 42 & & 2 & 2 & & & 1 & 10 & 105 \\
\hline \multirow{4}{*}{$\begin{array}{l}\text { Żagań- } \\
\text { Tomaszowo }\end{array}$} & 11.02 .2006 & & & & & & 3 & 5 & 22 & 2 & & & & & 32 \\
\hline & 18.02 .2007 & & & & & & 4 & 5 & 15 & 5 & & & 1 & & 30 \\
\hline & 01.02 .2008 & 1 & & & & & 4 & 4 & 12 & 6 & & & & & 27 \\
\hline & 07.02.2009 & & & & & & 4 & 3 & 25 & 6 & & & & & 38 \\
\hline \multirow{13}{*}{$\begin{array}{l}\text { Szprotawa- } \\
\text { Wiechlice }\end{array}$} & 10.02 .2004 & & & & & & 2 & & 3 & 1 & & & & 1 & 7 \\
\hline & 09.02 .2006 & & & & & & 9 & & 12 & 2 & & & & & 23 \\
\hline & 18.02 .2007 & & & & & & 6 & & 8 & 2 & & & & & 16 \\
\hline & 07.02.2009 & & & & & & 7 & 2 & 26 & 4 & & & & & 39 \\
\hline & 22.02 .2010 & & & & & & 8 & 1 & 38 & 12 & & & & 2 & 61 \\
\hline & 27.01 .2011 & & & & & & 11 & 2 & 55 & 9 & & & & & 77 \\
\hline & 09.02 .2012 & & & & & & 8 & - & 53 & 8 & & & & & 69 \\
\hline & 02.02 .2013 & & & & & & 5 & 3 & 51 & 17 & & & & 2 & 78 \\
\hline & 06.02 .2014 & & & & & & 6 & 1 & 60 & 9 & & & & & 76 \\
\hline & 10.02 .2015 & & & & & & 8 & 3 & 45 & 9 & & & 1 & & 66 \\
\hline & 14.02 .2016 & & & 1 & & & 1 & & 26 & 10 & & & & & 38 \\
\hline & 04.02 .2017 & 1 & & & & & 10 & 1 & 74 & 10 & & & & & 96 \\
\hline & 17.02 .2018 & & & & & & 4 & 4 & 56 & 16 & & & & 1 & 81 \\
\hline \multirow{7}{*}{ Templewo } & 11.02 .2012 & & & & & & 3 & & 32 & 2 & & & & 2 & 39 \\
\hline & $15.02 .2013^{*}$ & & & & & & 18 & & 22 & 2 & & & & & 42 \\
\hline & 12.01 .2014 & & & & & & 7 & & 1 & & & & 1 & 2 & 11 \\
\hline & 11.01.2015 & & & & & & 15 & & 26 & 1 & & & 1 & 1 & 44 \\
\hline & 19.01 .2016 & & 1 & & & & 10 & & 38 & 1 & & & 1 & & 51 \\
\hline & 11.02 .2017 & & & & & & 12 & & 61 & 2 & & & 1 & & 76 \\
\hline & 11.02 .2018 & & 1 & 6 & & & 17 & & 43 & 1 & & & & & 68 \\
\hline \multirow{7}{*}{$\begin{array}{l}\text { Stargard- } \\
\text { Kluczewo }\end{array}$} & $13.01 .2012^{* *}$ & 1 & 13 & 8 & & & 17 & & 2 & 12 & & & 432 & 11 & 496 \\
\hline & 15.02 .2013 & & 10 & 9 & & & 9 & & 3 & 5 & & & 217 & 6 & 259 \\
\hline & 11.02 .2014 & 2 & 14 & 5 & & & 11 & & 10 & 9 & & & 267 & 8 & 326 \\
\hline & 18.02 .2015 & 3 & 68 & 27 & & & 19 & & 19 & 9 & & & 307 & 5 & 447 \\
\hline & 21.01 .2016 & 15 & 81 & 28 & & 1 & 14 & & 13 & 9 & & & 275 & 13 & 449 \\
\hline & 31.01 .2017 & 8 & 73 & 20 & & 1 & 12 & & 13 & 5 & & & 179 & 11 & 322 \\
\hline & 11.02 .2018 & 10 & 67 & 27 & & & 14 & & 12 & 6 & & & 126 & 22 & 284 \\
\hline \multirow{7}{*}{ Wilkocin I } & 09.02 .2006 & & & & & & 13 & 8 & 8 & & & & & & 29 \\
\hline & 09.02 .2012 & 1 & & & & & 16 & 7 & 12 & 2 & & 2 & & & 40 \\
\hline & 03.02 .2013 & 5 & & & & & 17 & 11 & 12 & 5 & & & & & 50 \\
\hline & 06.02 .2014 & 10 & & & & & 19 & 11 & 17 & 4 & & & & 1 & 62 \\
\hline & 10.02 .2015 & 1 & & & 1 & & 15 & 15 & 16 & 6 & & & & & 54 \\
\hline & 13.02 .2016 & 2 & & & 2 & & 10 & 9 & 10 & 3 & & & & & 36 \\
\hline & 17.02.2018 & 2 & & 1 & & & 14 & 15 & 15 & 7 & & & & 1 & 55 \\
\hline \multirow{6}{*}{ Wilkocin II } & 09.02 .2012 & & & & & & 6 & 3 & 2 & 1 & & & & 1 & 13 \\
\hline & 03.02 .2013 & & & 3 & & & 7 & 4 & 3 & 2 & & & & & 19 \\
\hline & 06.02 .2014 & & & & & & 5 & 8 & 5 & 3 & & & & & 21 \\
\hline & 10.02 .2015 & 1 & & 6 & 1 & & 5 & 8 & 6 & 5 & & & & 1 & 33 \\
\hline & 13.02 .2016 & 2 & & 3 & & & 6 & 4 & 3 & 2 & & & & 1 & 21 \\
\hline & 17.02 .2018 & 3 & & 3 & & & 11 & 6 & 5 & 2 & & & & & 30 \\
\hline \multirow{3}{*}{ Trzebień } & 09.02 .2006 & & & & & & 1 & 1 & & & & & & & 2 \\
\hline & 09.02 .2012 & & & & & & 2 & 4 & & & & & & & 6 \\
\hline & 06.02 .2014 & & & & & & 1 & 1 & & & & & & & 2 \\
\hline Chocianów & 12.02 .2016 & & & & & & 19 & & 2 & & & & & 1 & 22 \\
\hline
\end{tabular}

